\title{
NETWORKING IN A DESTINATION FROM THE PERSPECTIVE OF VIRTUAL RELATIONSHIPS AND THEIR SPATIAL DIMENSION
}

\author{
Markéta BOBKOVÁ ${ }^{1}$, Andrea HOLEŠINSKÄ ${ }^{1}$
}

DOI: 10.21163/GT_2017.122.02

\begin{abstract}
:
From the economic-geographical approach point of view, a tourism destination is traditionally regarded as a defined geographical area. However, the destination can be considered as a socio-economic system composed of a variety of entities, with many certain types of links among them. Increasing pressure on the destination competitiveness requires more complex methods for investigating internal links and the description of their structures. Using a network analysis in combination with a spatial perspective could provide relevant results for understanding collaborative relationships. This paper focuses on the network of relations that are established due to the participation in the tourism product - the Olomouc visitor card project. The core of the network analysis lies in the website links among stakeholders who joined the Olomouc visitor card project. The main idea is that these virtual relationships may also reflect a social process. Hence, the paper measures the quantitative network characteristics of tourism destination web space and visualizes the existing network on a map. Finally, the results are discussed in the context of tourism destination governance.
\end{abstract}

Key-words: network analysis, tourist card, virtual relationship, tourism destination governance, Czech Republic

\section{INTRODUCTION}

Tourism destination is a part of geographical space within which the visitor enjoys various types of travel experiences (Goeldner \& Ritchie, 2003). It can be also defined as a bundle of tourist attractions and services concentrated in a particular region provided by different stakeholders from the public, private and non-profit sectors in relation to the tourism potential of the area. Concentration of various attractions and services in the destination can have a character of agglomeration effect. Pařil et al. (2015) provide more information about the agglomeration effects connected with space.

From the economical point of view, the destination is considered as a tourism product that offers visitors the so-called service supply chain linked to a particular territory. The destination visitor card is one of the best examples. This kind of tourism product provides the great opportunity for encouraging cooperative activities among stakeholders. Regarding the complexity of relationships and links, the destination is perceived as a network system (March \& Wilkinson, 2009; Baggio, 2008).

The cooperative behaviour of tourism stakeholders has been explored by several researchers, both foreign (e.g., Jamal \& Getz, 1995; de Araujo \& Bramwell, 2002; Baggio, 2008; Lemmetyinen, 2010; Kylänen \& Rusko, 2011; Beritelli, 2011) and Czech (Holešinská \& Bobková, 2015; Bobková, 2016). They emphasize the need for cooperation and the importance of networking within a tourism destination. Their findings show that the

\footnotetext{
${ }^{1}$ Masaryk University, Faculty of Economics and Administration, 60200 Brno, Czech Republic, marketa.bobkova@econ.muni.cz; holesinska@econ.muni.cz.
} 
effectiveness of cooperation increases when stakeholders focus on the needs of visitors and adapt them into their offer in the form of a tourism product (Holešinská, 2013). This approach based on the participation of the stakeholders leads to the new form of network management (Bobková, 2015). The formal and informal relationships between the local government and industry have a considerable positive effect (Dredge, 2006). Therefore, strengthening the public-private partnerships should be the main concern for policymakers and managers (Holešinská \& Novotná, 2014). For that reason, cooperation and involvement in appropriate strategic networks represent a precondition for a competitive destination (Tinsley \& Lynch, 2001; Baggio, 2008). This integration is related to the need to minimize possible negative impacts and increase customer satisfaction. Collaboration and networking stimulate interest in the sustainable development of the destination resulting in the greater attractiveness of the region for further investment (Hall \& Kirkpatrick, 2005). The management of a tourism destination in the form of networks could be thus considered as one of the possible approaches to destination governance structures (e.g., Pechlaner, Volgger \& Herntrei, 2012).

The aim of this research paper is to evaluate the character of the stakeholders' cooperative behaviour in the perspective of the virtual relationships and to show the spatial dimension of the network relations.

\section{STUDY SITE}

For this study, the tourism product in the form of the destination tourist card offering free admission or discounts to card holders in the Olomouc region was chosen (Fig. 1). The Olomouc region $\left(49^{\circ} 43^{\prime} \mathrm{N}\right.$ and $\left.17^{\circ} 07^{\prime} \mathrm{E}\right)$ is an administrative unit of the Czech Republic, located in the north-western and central part of its historical region of Moravia and in a small part of the historical region of Czech Silesia.

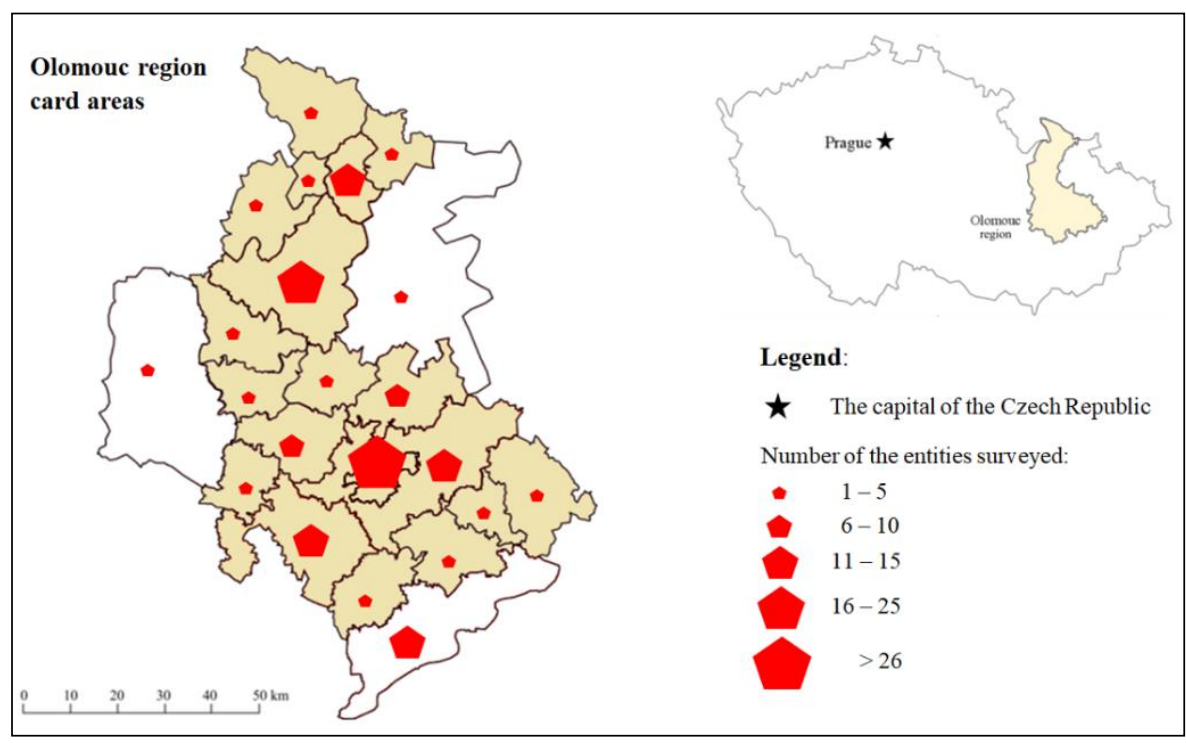

Fig. 1 Location of the study area (Source: original work) 
The northern part of the region is of a mountainous nature. On the other hand, the southern part of the region consists of the Hanakian lowland. This region offers a great variety of natural as well as cultural and historical points of interest, e.g., protected landscape area of the Jeseníky, protected landscape area of Litovelské Pomoraví, water reservoir Dlouhé Stráně, many caves, castles, museums, or town halls (Vystoupil et al., 2006).

The Holy Trinity Column in Olomouc was inscribed into the UNESCO list in 2000. In addition to 19 tourist localities from the Olomouc region, another three neighbouring areas belonging to other regions (the Moravian-Silesian, Zlín and Pardubice Region) joined this collaborative project of the tourist card. For that reason, they are included in the analysis.

\section{METHODOLOGY}

The destination can be viewed from the point of network theory as an interorganizational network of independent entities (Baggio et al., 2008) or as a set of nodes and relationships within a destination (Pavlovich, 2003). To measure the network characteristics of a tourism destination, quantitative network analysis methods are used (e.g., Timur \& Getz, 2008; Gajdošík, 2015; Baggio et al., 2008).

Nowadays, the network analysis seems to be the most useful approach to the understanding of cooperation processes taking place in destinations (Żemła, 2016). The specific set of linkages among a defined set of entities in the network may be used to interpret the behaviour of the entities involved (Mitchell, 1969). Moreover, the analysis is theoretically important as it enriches the methodologies not only for analysing the relationships but also for conceptualizing and identifying tourism functional zones ( $\mathrm{Li}$ et al., 2015).

As far as it is known that the spatial analysis is a fundamental subject of tourism geography as a synthesizing approach, the research applies the network analysis in combination with a spatial perspective (e.g., Luo \& MacEachren, 2014). A combination between the network and the geographical data has the potential for understanding the relations between constructing social or virtual relationships and spatial consequences. According to Baggio, Scott \& Wang (2007), the analysis of tourism destination web space may also reflect the characteristics of the structure of the social network from which it originates as the structure of hyperlinks is based on the individuals or organisations that own these websites.

The data are processed in the program Gephi 0.9.1. It is a tool for data analysts, which can offer the most common metrics for network analysis. It calculates all selected quantitative characteristics and visualizes the cooperative behaviour. Gephi has its own Data Laboratory with an Excel-like interface to manipulate data columns, search and transform the data. It has the ability to create the network graphs up to 100,000 nodes and 1,000,000 edges (Bastian et al., 2009). Layout algorithms give the shape to the graph. Moreover, it enables to use the plugin latitude/longitude coordinating nodes position in the network, depicted in degrees.

To describe a complex network and fully characterise the topology and the behaviour of such systems, the density of network, the average path length, the average degree, and the average clustering coefficient are measured. For illustration, the characteristics are compared to a random network. The structural characteristics are then interpreted in terms of the complexity of tourism product and its spatial dimension. 
Considering this, the key hypothesis of the research paper is Entities from localities with certain prerequisites for tourism are more intensively involved in the cooperative activities.

To learn more about the success of the cooperative relationships established within the tourism product (Olomouc visitor card), the results are compared to the number of tourists in the collective accommodation establishments (Czech Statistical Office, 2016). The relative linear relationship is determined by the Pearson correlation coefficient $r$ :

$$
r=\frac{\sum(x-\bar{x})(y-\bar{y})}{\sqrt{\sum(x-\bar{x})^{2} \sum(y-\bar{y})^{2}}}
$$

\subsection{Data sample}

Tourism service providers and other entities related to tourism supply (e.g., tourism attractions, facilities or infrastructure) involved in this regional tourism product were identified by using official lists provided by the Olomouc region. Consequently, the links among their official websites were investigated. All links are considered of directed nature. The size of the network examined is 172 nodes in 22 tourism localities together.

\section{RESULTS AND DISCUSSION}

\subsection{Network analysis}

The analysis allowed the identification of nodes connected by a certain number of links. A network is mathematically represented by a directed graph with 172 nodes and 599 edges between the pairs of nodes. These main characteristics as edges and nodes represent the size of network and the number of cooperative relations. To describe a complex network and fully characterise the topology and the behaviour of such systems, the graph density, the average path length, the average degree, and the average clustering coefficient are measured. For illustration, the characteristics are compared to a random network (Table 1).

Table 1. Quantitative characteristics of the network analysis

\begin{tabular}{|l|l|l|}
\hline Quantitative characteristics & Research area & Random network \\
\hline Number of nodes & 172 & 172 \\
\hline Number of edges & 599 & 734 \\
\hline Density & 0.02 & 0.025 \\
\hline Average degree & 6.965 & 8.535 \\
\hline Average clustering coefficient & 0.359 & 0.029 \\
\hline Average path length & 3.367 & 2.793 \\
\hline
\end{tabular}

Source: original work

First, the density of network is worth mentioning. A completely linked network has a density of 1 . In this research case, the ratio between the number of actual links and the maximum possible number of relations is 0.02 . 
A total of 154 nodes are connected (it means $89.53 \%$ of the original set) and 18 nodes are outside the network. The level of cooperative activities is better reflected by the average degree.

On average, every entity has almost seven (6.965) cooperative relations with other subjects. The intensity of cooperation, based on the clustering coefficients determines how well the neighbours of a node are connected. To put it simply, it measures the tendency to cluster together. The average path length shows how many edges must be overcome to connect two nodes. In this research case, it is the average number of clicks (3.367) which lead the visitor from one website to another.

To interpret the structural characteristics in terms of the complexity of tourism product, there are certain horizontal and vertical links between accommodation facilities, restaurants, sports and natural attractions as well as cultural and historical monuments. This implies the synergy effect, i.e., the economics of scope and the economics of scale (Bieger $\&$ Weibel, 1998). Further findings reveal that the tourist information centre in Olomouc has the dominant position in the network. It refers to a large number of attractions and services in the destination and, by its very nature; it provides a complex set of links. On the other hand, the involvement of other entities despite their lower degree completes the network, which becomes a tool for specialization.

The most valuable findings was generated by the program ForceAtlas 2 layout that helps to visualize the structural proximity within the research network and thus, it shows the effect of forces on the nodes. This component of the interconnected nodes is illustrated in Fig. 2. Gephi customizes colours or size of the nodes to bring sense to the network representation. The size of the nodes is proportional to their degree and the nodes colour indicates the locality to which they belong. It is visible that the nodes from the same geographical locality are clustered more intensively to each other and regardless their character. This finding implies the law of gravity that is the most noticeable in the lightgreen-coloured nodes (Šumperk locality with important spas, museums, ski resorts and hotels) and the violet-coloured nodes (Olomouc locality). The virtual relationship thus occurs especially between the geographically close nodes representing tourist attractions.

The special dimension of the virtual relationships is shown in Fig. 3. The left-side map depicts the geographical distribution of the nodes and the intensity of the relationships in the space. The density of the network is significant in tourist attractive localities such as Olomouc, Jeseníky, and Šumperk locality. The right-side projection of the network takes into account the degree of the nodes. This provides a new look at the tourism destination as it visualizes the hyperlinks at the level of the individual entities in the real space. In other words, it identifies tourism functional zones. The spatial distribution and network characteristics help to identify the nodal points, and through this knowledge, it becomes possible for the destination management organisations to develop appropriate strategies and policies.

This research study also examines the qualitative aspect of the virtual relationships among stakeholders. The correlation coefficient indicates a very high direct linear dependence between the entities and the number of tourists in the collective accommodation establishments (Fig. 4).

There is evidence that the cooperative relationships are intensive in the localities with very good prerequisites for tourism (Vystoupil et al., 2006). Moreover, the network linkage shows that the involvement in the common tourism product (the destination visitor card) stimulates the destination performance (the number of tourists). 


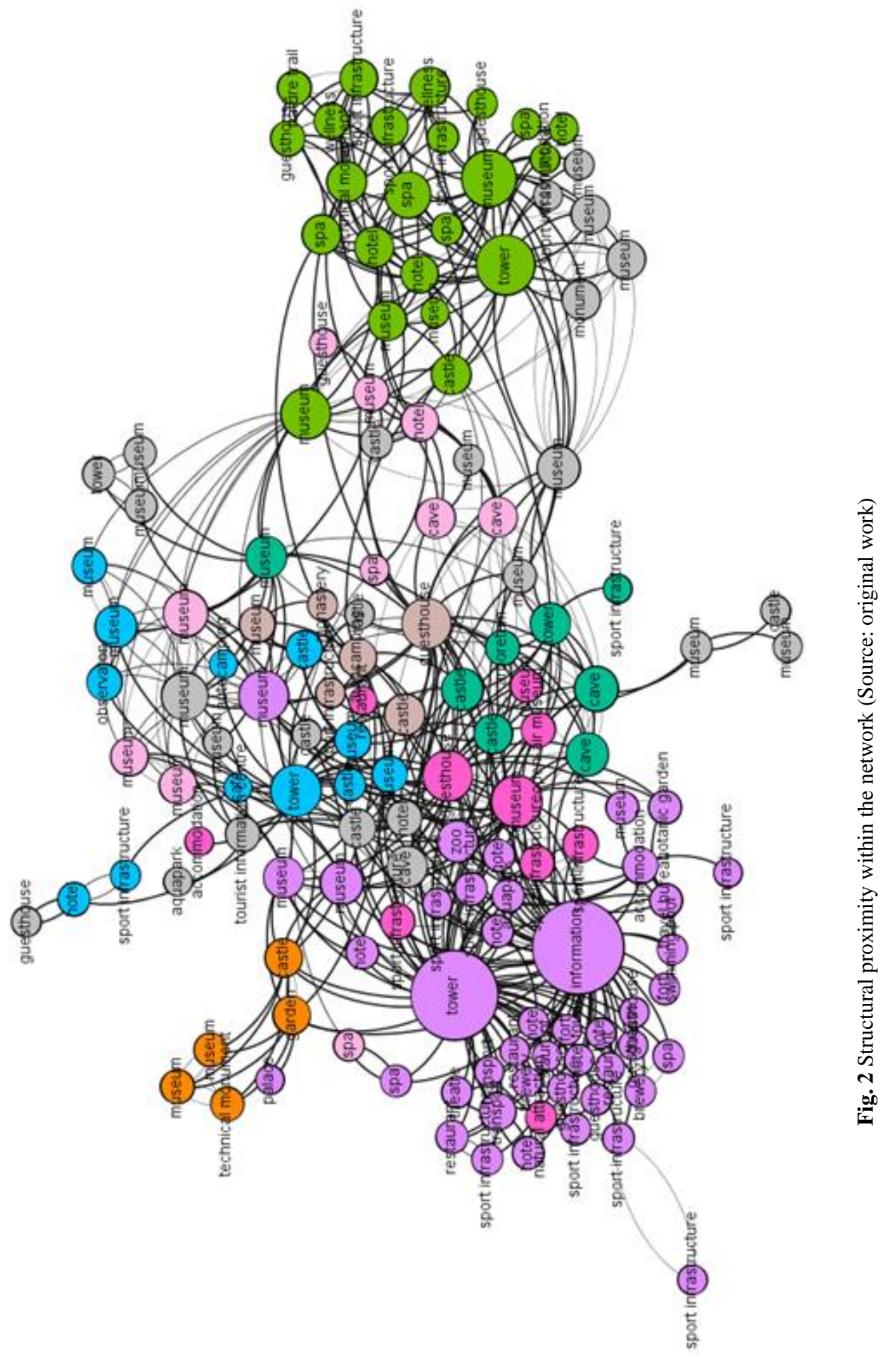




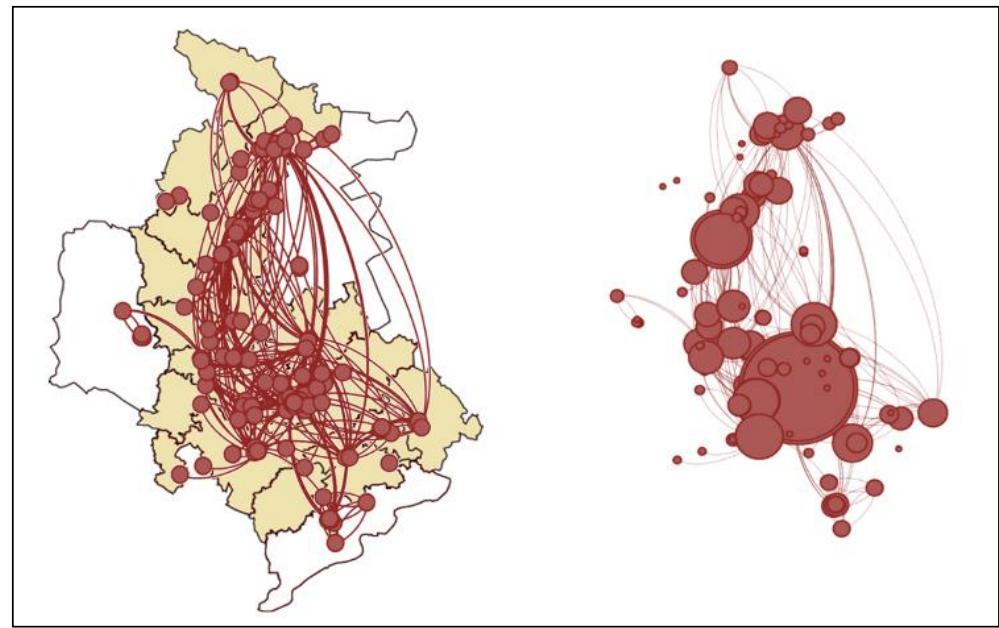

Fig. 3 Spatial visualisation of the hyperlinks (Source: original work)

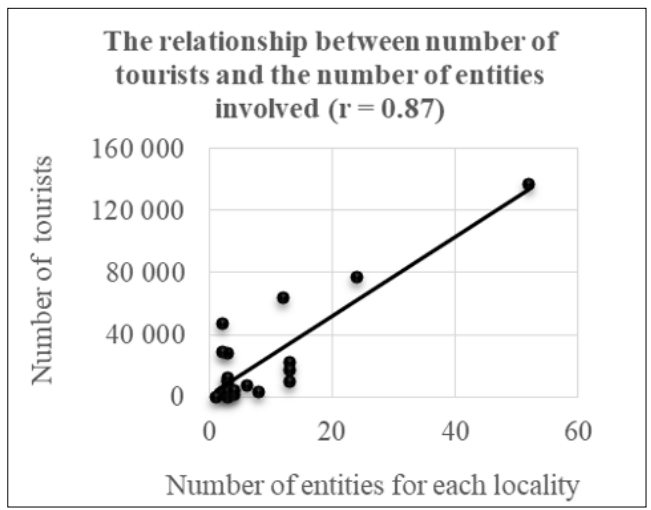

Fig. 4 The relative linear relationship

(Source: original work based on the data from the Czech Statistical Office, 2016)

The research results and their spatial visualisation verify that the established partnership within the tourism product and the involvement in the network of joint entities contribute to the destination development and thus enhancing the destination competitiveness.

\subsection{Limitations}

Network analysis has a long tradition in many fields of physical, chemical, biological and social sciences. On the other hand, it is a relatively new approach in the tourism studies. In spite of the novelty of the approach, network analysis provides a number of useful outcomes and applications in tourism research. 
It visualizes complex sets of relationships and simplifies them. Networks of relationships can subsequently be compared between destinations. Moreover, it can visualize how a network evolves over time. The application of network analysis is of benefit to the research, which reveals very interesting results; however, there are certain limits that must be considered when explaining the findings.

Firstly, the research works with the virtual relationships and although the structure of the hyperlinks can reflect the characteristic of the social network, the qualitative aspect of the relations/linkage is missing. For this reason, the results were compared with the real performance of the destination - the number of tourists in collective accommodation establishments.

Secondly, as the object of the research is the virtual relationships, the results do not indicate the quality of the provided tourism product (the destination visitor card). This is the task of customers to express their satisfaction and loyalty, and hence the quality. Considering this, the qualitative analysis should be applied.

\section{CONCLUSIONS}

The paper discusses a new perspective on the relations in a destination. The destination is introduced as the system of virtual relations in a spatial context. The research is based upon the network of hyperlinks among the websites of destination system components (stakeholders) participating in the tourism product (the destination visitor card). The connections among their websites form a network, whose quantitative characteristics are described to understand the cooperative relationships and to visualize the virtual cooperative behaviour.

The findings show that the existing network becomes a tool for specialization, however, generally, the intensity of cooperation is more or less moderate (Alter \& Hage, 1993). The spatial dimension of the network identifies that the relations are more intensive within the localities, e.g., Olomouc, Jeseníky, and Šumperk locality. The law of gravity is performed. On the other hand, there is evidence of individual entities, e.g., tourist information centre in Olomouc with high centrality. Such entities (stakeholders) are important for encouraging the destination management process.

The final conclusion is that the research verifies the above stated hypothesis that the entities located in the areas with (very) good prerequisites for tourism are more intensively involved in the cooperative relationships. Moreover, the evaluated character of the stakeholders' cooperative behaviour demonstrates the existence of synergies that contribute to the destination competitiveness - measuring by the number of tourists in the collective accommodation establishments. Furthermore, the research results provide the potential for the improvement of information exchange and governance in destinations.

\section{ACKNOWLEDGMENT}

This article was supported by the project Specific University Research at Masaryk University in Brno, Faculty of Economics and Administration, no. MUNI/A/1046/2016. 


\section{R E F E R E N C E S}

Alter, C. \& Hage, J. (1993) Organizations Working Together. London: Sage.

Baggio, R., Scott, N. \& Wang, Z. (2007) What network analysis of the WWW can tell us about the organisation of tourism destinations. CAUTHE 2007: Tourism-Past Achievements, Future Challenges, 262.

Baggio, R. (2008) Network analysis of a tourism destination. PhD Thesis, Australia: University of Queensland.

Baggio, R., Cooper, C. \& Scott, N. (2008) Destination networks: four Australian cases. Annals of Tourism Research, 35(1), 169-188.

Bastian, M. et al. (2009) Gephi: an open source software for exploring and manipulating networks. ICWSM Conference, 8, 361-362.

Beritelli, P. (2011) Cooperation among prominent actors in a tourist destination. Annals of Tourism Research, 38, 607-629. DOI:10.1016/j.annals.2010.11.015.

Bieger, T. \& Weibel, C. (1998) Möglichkeiten und Grenzen des kooperativen Tourismusmarketings Schaffung von Tourismussystemen als Strategien gegen destinationsähnliche Konkurrenzprodukte. In P. Keller (ed.) Destination Marketing - Scopes and Limitations. St. Gallen: AIEST. pp. 167-200.

Bobková, M. (2015) Research topics in tourism policy. In 10. mezinárodní konference Aktuální problémy cestovního ruchu. Sborník z mezinárodní konference. Jihlava: Vysoká škola polytechnická Jihlava, 22-33.

Bobková, M. (2016) Network structures and their impact on destination competitiveness - a case study of Vsacko (Czech Republic). In Sustainability of Rural Areas in Practice. Conference Proceedings from International Scientific Conference. Nitra: Slovak University of Agriculture in Nitra, 123-132. ISBN 978-80-552-1574-7.

Czech Statistical Office (2016) Public Database [statistics]. Retrieved from https://vdb2.czso.cz/ vdbvo2/faces/en/index.jsf. [Accessed 21st January 2017].

De Araujo, L. \& Bramwell, B. (2002) Partnership and regional tourism in Brazil. Annals of Tourism Research, 29(4), 1138-1164. ISSN 0160-7383. DOI 10.1016/S0160-7383(02)00033-6.

Gajdošík, T. (2015) Network analysis of cooperation in tourism destinations. Czech Journal of Tourism, 4(1), 26-44.

Goeldner, C. R. \& Ritchie, J. B. (2006) Tourism: Principles, practices, philosophies. John Wiley \& Sons.

Hall, D. R. \& Kirkpatrick, I. (2005) Rural tourism and sustainable business (Vol. 26). Channel view publications.

Holešinská, A. (2012) Destinačni management jako nástroj regionální politiky cestovního ruchu. 1. vyd. Brno: Masarykova univerzita. ISBN 978-80-210-5847-7.

Holešinská, A. (2013) DMO-A dummy-made organ or a really working destination management organization. Czech Journal of Tourism, 2(1), 19-36.

Holešinská, A. \& Bobková, M. (2014) Destination networks as a tool for minimizing risk and improving the performance of a destination. Czech Journal of Tourism, Brno: Masarykova univerzita, 4(2), 90-102. ISSN 1805-3580. doi:10.1515/cjot-2015---0006.

Holešinská, A. \& Novotná, M. (2014) Tourism destination governance v kontextu teoretických poznatků. In XVII. mezinárodni kolokvium o regionálních vědách. Sborník příspěvků. Brno: Masarykova univerzita, 796-801. ISBN 978-80-210-6840-7. DOI 10.5817/cz.muni.p210-68402014-103.

Jamal, T. \& Getz, D. (1995) Collaboration theory and community tourism planning. Annals of Tourism Research, 22(1), 186-204. ISSN 0160-7383. DOI 10.1016/0160-7383(94)00067-3.

Kylänen, M. \& Rusko, R. (2011) Unintentional coopetition in the service industries: The case of Pyhä-Luosto tourism destination in the Finnish Lapland. European Management Journal, 29(3), 193-205. ISSN 0263-237. DOI 10.1016/j.emj.2010.10.006.

Lemmetyinen, A. (2010) The Coordination of Cooperation in Tourism Business Networks. Turku: Turku School of Economics. ISBN 978-952-249-078-0. 
Li, M., Fang, L., Huang, X. \& Goh, C. (2015) A spatial-temporal analysis of hotels in urban tourism destination. International Journal of Hospitality Management, 45, 34-43.

Luo, W. \& MacEachren, A. M. (2014) Geo-social visual analytics. Journal of spatial information science, 8, 27-66.

March, R. \& Wilkinson, I. (2009) Conceptual tools for evaluating tourism partnerships. Tourism Management, 30, 455-462. ISSN 0261-5177. DOI 10.1016/j.tourman.2008.09.001.

Mitchell, J. C. (1969) The concept and use of social networks. In J. C. Mitchell (Ed.) Social networks in urban situations. Manchester : University of Manchester Press.

Olomouc region (2017) Catalogue Olomouc region Card. [Online]. Available from: http://www.olomoucregioncard.cz/public/files/file/pdf/ORC_brochure_2017.pdf [Accessed 17th March 2017].

Pařil, V. et al. (2015) Agglomeration effects of the Brno city (Czech Republic) as exemplified by the population labour mobility. Geographia Technica, 10(1), 66-76.

Pavlovich, K. (2003) The evolution and transformation of a tourism destination network: the Waitomo Caves, New Zealand. Tourism Management, 24(2), 203-216.

Pechlaner, H., Volgger, M. \& Herntrei, M. (2012) Destination management organizations as interface between destination governance and corporate governance. Anatolia, 23(2), 151-168.

Timur, S. \& Getz, D. (2008) A network perspective on managing stakeholders for sustainable urban tourism. International Journal of Contemporary Hospitality Management, 20(4), 445-461.

Tinsley, R. \& Lynch, P. (2001) Small tourism business networks and destination development. International Journal of Hospitality Management, 20(4), 367-378.

Vystoupil, J. et al. (2006) The Altas of Tourism in the Czech Republic (Atlas cestovního ruchu České republiky). Prague: Ministry for Regional Development.

Żemła, M. (2016) Tourism destination: The networking approach. Moravian Geographical Reports, 24(4), 2-14. 